\title{
PENGUJIAN MODEL HOT FIT PADA SISTEM INFORMASI MANAJEMEN OBAT DI INSTALASI FARMASI RSGMP UNSOED PURWOKERTO
}

\author{
Ilma Soraya1, Wiwiek Rabiatul Adawiyah ${ }^{2}$, Eman Sutrisna ${ }^{3}$ \\ 1,2,3Fakultas Ekonomi dan Bisnis, Universitas Jenderal Soedirman, Indonesia \\ Email corresponding author: soraya.ilma@yahoo.com
}

\begin{abstract}
Abstrak
Sistem informasi manajemen obat sangat dibutuhkan oleh instalasi farmasi rumah sakit untuk menjaga mutu rumah sakit, melindungi keselamatan pasien dan mendukung pengambilan keputusan yang cepat dan tepat. Penerapan sistem informasi manajemen obat di instalasi farmasi RSGMP Unsoed selama ini belum berjalan dengan baik sehingga sistem informasi yang dilakukan masih manual. Sistem di instalasi farmasi yang sudah diterapkan memerlukan evaluasi, perbaikan, dan peningkatan untuk menyesuaikannya dengan perkembangan jaman. HOT Fit model merupakan model yang lengkap dan paling sesuai dengan kondisi permasalahan yang ada dalam penelitian ini. Fokus utama penelitian diarahkan pada hubungan antara aspek manusia, aspek organisasi, aspek teknologi, serta kemanfaatan yang dihasilkan sistem. Tujuan umum penelitian ini adalah untuk menguji model HOT Fit pada sistem informasi manajemen obat di instalasi farmasi RSGMP Unsoed Purwokerto. Jenis penelitian ini adalah penelitian analitik dengan pendekatan kuantitatif. Total responden penelitian berjumlah 43 orang. Metode pengumpulan data yang digunakan dalam penelitian ini adalah wawancara dengan instrumen berupa kuesioner. Pengujian hipotesis dilakukan dengan melakukan uji regresi menggunakan SPSS. Hasil penelitian ini menunjukan seluruh jalur hipotesis di kerangka model HOT Fit yang di uji memiliki pengaruh satu sama lain, kecuali untuk variabel organisasi yang tidak memiliki pengaruh terhadap variabel kemanfaatan.
\end{abstract}

Kata Kunci: Model HOT Fit, Sistem Informasi, Instalasi Farmasi

\begin{abstract}
Drug management information system is needed by hospital pharmacy installations to maintain hospital quality, protect patient safety and to make decision making more fast and appropriate. The application of the drug management information system at the RSGMP Unsoed pharmacy installation has not been running well so that the information system carried out manually. Systems in pharmaceutical installations that have been implemented need to be evaluated, make an improvement, and improvement to adjust them to the times. HOT Fit model is a complete model and suits the best with conditions of the problems in this study. The main focus of research is directed at the relationship between human aspects, organizational aspects, technology aspects, and the net benefits generated by the system. The objective of this study was to test the HOT Fit model on drug management information systems at RSGMP Unsoed Purwokerto pharmacy installation. This type of research is analytical research with a quantitative approach. Total research respondents were 43 people. The method used for collecting data in this study were interviews with instruments in the form of questionnaires. Hypothesis testing is done by conducting a regression test using SPSS. The results of this study show that all hypothetical pathways in the framework of the HOT Fit model tested have influence with each other, except for organizational variables that have no effect to the net benefit.
\end{abstract}

Keywords: HOT Fit Models, Information System, Pharmacy Installations

\section{PENDAHULUAN}

Obat-obatan merupakan hal yang krusial dan sangat dibutuhkan untuk proses perawatan maupun proses penyembuhan pasien. Obat-obatan harus dikelola dengan baik, agar tidak terjadi kerugian secara fisik maupun material (Anand dkk., 2013). Pusat dari logistik dan akses obatobatan di rumah sakit adalah instalasi farmasi. Farmasi rumah sakit harus memberikan pelayanan farmasi secara efektif dan efisien untuk memastikan bahwa pasien mendapatkan pelayanan dengan kualitas tertinggi (Departemen Kesehatan RI, 2010). Instalasi farmasi sebuah rumah sakit dapat dikelola dengan baik apabila terdapat sistem manajemen informasi yang baik. 
Sistem informasi menjadi suatu hal yang penting guna menunjang pencapaian derajat kesehatan masyarakat, maka dari itu pemerintah Indonesia telah memberikan kebijakan untuk mewajibkan rumah sakit menyelenggarakan sistem informasi rumah sakit dalam Peraturan Menteri Kesehatan Republik Indonesia Nomor 1171/MENKES/PER/VI/2011 tentang Sistem Informasi Rumah Sakit.

Sistem informasi farmasi adalah sistem yang mendukung distribusi dan pengelolaan obat-obatan terlarang, mengidentifikasi jenis intervensi, menentukan jumlah persediaan, pelaporan dan pengelolaan biaya, dan meningkatkan aksesibilitas informasi (Nasir dkk., 2014). Sistem informasi manajemen obat sangat dibutuhkan oleh Instalasi Farmasi Rumah Sakit (IFRS) untuk menjaga mutu rumah sakit, melindungi keselamatan pasien dan mendukung pengambilan keputusan yang cepat dan tepat, karena jika pengelolaan informasi dilakukan secara manual, banyak data yang terabaikan dan dampaknya sangat dirasakan dalam pengambilan keputusan (Dwibarto, 2017). Rumah Sakit Gigi dan Mulut Pendidikan (RSGMP) merupakan penyelenggara pelayanan kesehatan gigi dan mulut yang juga digunakan sebagai sarana proses pembelajaran, pendidikan dan penelitian bagi profesi tenaga kesehatan kedokteran gigi dan tenaga kesehatan lainnya. RSGMP Unsoed menyediakan pelayanan kesehatan gigi dan mulut oleh dokter gigi pada klinik Unit Pelayanan Umum serta mahasiswa profesi kedokteran gigi pada klinik Integrasi (RSGMP Unsoed, 2015).

Data Rekam Medis RSGMP Unsoed tahun 2018 menunjukkan jumlah kunjungan pasien rawat jalan RSGMP Unsoed yang semakin meningkat setiap bulannya. Meningkatnya kunjungan pasien di RSGMP Unsoed menyebabkan semakin bertambahnya tuntutan dan kebutuhan pelayanan yang diberikan kepada pasien dan keluarganya. Maka dari itu RSGMP Unsoed membutuhkan suatu sistem yang dapat mempercepat pelayanan kepada pasien yang bertujuan untuk memperoleh akurasi data yang lebih cepat dalam pelayanan kefarmasian. Menurut Satibi (2015), semakin tinggi kunjungan pasien maka kebutuhan akan obat semakin meningkat dan persediaan obat yang ada di instalasi farmasi semakin berkurang sehingga diperlukan suatu informasi perencanaan yang baik akan persediaan obat yang sesuai dengan kebutuhan masyarakat. Berdasarkan hasil wawancara dengan Direktur RSGMP Universitas Jenderal Soedirman ditemukan bahwa penerapan sistem informasi manajemen obat di IFRS selama ini belum berjalan dengan baik karena sistem informasi yang dilakukan masih manual.

Diketahui pula masih terdapat kendala-kendala dalam pengelolaan obat di IFRS, antara lain masih ada perencanaan dalam stok obat yang belum sesuai, kesalahan dalam melakukan pencatatan dan pelaporan pengeluaran obat. Dari instalasi farmasi juga didapatkan informasi bahwa masih banyak permasalahan sistem informasi manajemen ini seperti aplikasi Sistem Informasi Manajemen RS yang belum cocok dengan kebutuhan instalasi farmasi, sehingga pengisian data farmasi tidak optimal. Selain itu sumber daya manusia yang ada masih belum cukup memiliki kemampuan untuk menginput data di instalasi farmasi. Kendala-kendala ini merupakan dampak dari sistem manajemen yang kurang baik dan akan sangat memengaruhi kualitas pelayanan pasien di instalasi farmasi. Sistem di instalasi farmasi yang sudah diterapkan memerlukan evaluasi, perbaikan, dan peningkatan untuk menyesuaikannya dengan perkembangan jaman. Berdasarkan uraian diatas, untuk mengkaji lebih mendalam mengenai penggunaan sistem informasi manajemen obat di RSGMP Universitas Jenderal Soedirman maka diperlukan suatu evaluasi.

Evaluasi merupakan suatu usaha nyata untuk mengetahui kondisi sebenarnya suatu penyelenggaraan sistem informasi. Dengan evaluasi tersebut, capaian kegiatan penyelenggaraan suatu sistem informasi dapat diketahui dan tindakan lebih lanjut dapat direncanakan untuk memperbaiki kinerja penerapannya (Murnita dkk., 2016). HOT Fit adalah salah satu model kerangka teori yang dipakai untuk mengevaluasi sistem informasi dalam bidang pelayanan kesehatan (Yusof dkk., 2008). HOT Fit model merupakan model yang lengkap dan paling sesuai dengan kondisi permasalahan yang ada dalam penelitian ini. Fokus utama penelitian diarahkan pada hubungan antara aspek human (manusia) sebagai pengguna yang terdiri dari penggunaan sistem dan kepuasan pengguna, aspek organization (organisasi) yang terdiri dari struktur dan lingkungan organisasi, aspek technology (teknologi) yang terdiri dari kualitas sistem, kualitas informasi, dan kualitas layanan, serta terhadap net benefit (kemanfaatan) yang dihasilkan sistem 
informasi manajemen di instalasi farmasi RSGMP Universitas Jenderal Soedirman. Tujuan penelitian ini adalah untuk menguji model HOT Fit pada sistem informasi manajemen obat di instalasi farmasi RSGMP Unsoed Purwokerto.

\section{TINJAUAN PUSTAKA}

\section{Sistem Informasi Manajemen}

Sistem informasi adalah kumpulan elemen yang saling berhubungan satu sama lain yang membentuk satu kesatuan untuk mengintegrasikan data, memproses dan menyimpan serta mendistribuskan informasi untuk mendukung pembuatan keputusan dan pengawasan dalam organisasi (Rozanda dan Masriana, 2017). Penyediaan pelayanan kesehatan yang bermutu dengan mengelola berbagai jenis data dengan baik dalam suatu sistem informasi penting untuk pengembangan dan pencapaian tujuan organisasi (Mulyadi, 2013). Penggunaan sebuah sistem informasi manajemen (SIM) farmasi di rumah sakit sangat bermanfaat.

Instalasi farmasi biasanya akan dibuatkan program komputerisasi dan dikembangkan dengan sistem jaringan komputer berupa local area network (LAN) yang terpusat di SIM RS. Menurut Noerlina (2009), aplikasi SIM RS terdiri dari beberapa modul yaitu registrasi pasien, antrian, manajemen rawat jalan, farmasi, akuntansi, dan rekam medis. Ruang lingkup pada SIM Farmasi antara lain pengelolaan pengelompokan persediaan, permintaan pembelian persediaan, pengelolaan penerimaan dan pendistribusian persediaan, pencatatan data transaksi, stock opname, pemantauan kondisi persediaan (kadaluarsa), penghapusan persediaan yang rusak dan kadaluarsa serta pembuatan dokumen dan laporan persediaan gudang dan instalasi farmasi (Yulianti dkk., 2015).

\section{Model Evaluasi HOT Fit}

Telah banyak dilakukan penelitian terhadap evaluasi implementasi sistem informasi di bidang pelayanan kesehatan, salah satunya dengan menggunakan metode HOT Fit Model (Hariningsih, 2014). Metode evaluasi HOT Fit memperjelas semua komponen yang terdapat dalam sistem informasi yaitu komponen Manusia (Human), Organisasi (Organization), dan Teknologi (Technology). Komponen manusia menilai sistem informasi dari sisi penggunaan sistem (system use) pada frekuensi dan luasnya fungsi dan penyelidikan sistem informasi. Komponen ini juga menilai sistem dari aspek kepuasan pengguna (user satisfaction) (Ali dkk., 2015). Kepuasan pengguna adalah keseluruhan evaluasi dari pengalaman pengguna dalam menggunakan sistem informasi dan dampak potensial dari sistem informasi (Murnita dkk., 2016).

Komponen organisasi dinilai dari kepemimpinan, dukungan dari top manajemen dan dukungan staf. Lingkungan organisasi terdiri dari sumber pembiayaan, pemerintahan, politik, kompetisi, hubungan interorganisasional dan komunikasi (Rozanda dan Masriana, 2017). Komponen teknologi terdiri dari kualitas sistem (system quality), kualitas informasi (information quality) dan kualitas layanan (service quality). Kualitas sistem dalam sistem informasi menyangkut keterkaitan fitur dalam sistem termasuk performa sistem dan user interface. Kemudahan penggunaan, kemudahan untuk dipelajari, waktu respon, kegunaan, ketersediaan, fleksibilitas, dan sekuritas. Kriteria yang dapat digunakan untuk menilai kualitas informasi antara lain adalah kelengkapan, keakuratan, ketepatan waktu, ketersediaan, relevansi, konsistensi, dan data entry.

Kualitas layanan berfokus pada keseluruhan dukungan yang diterima oleh service provider sistem atau teknologi. Kualitas layanan dapat dinilai dengan kecepatan respon, jaminan, empati dan tindak lanjut layanan (Yusof dkk., 2008). Menurut Sheikhtaheri dkk. (2013), seluruh petugas di rumah sakit yang dapat mengakses obat harus mampu mengakses sistem informasi manajemen obat agar penyelenggaran sistem informasi obat dapat tercapai dengan baik. Petugas RSGMP Unsoed yang dapat mengakses sistem ini berjumlah 43 orang yang terdiri dari 2 orang apoteker, 1 orang tenaga teknis kefarmasian, 1 orang bagian gudang farmasi, 1 orang bagian pengadaan farmasi, 2 orang dokter IGD, 10 orang perawat IGD, 5 orang dokter gigi Unit Pelayanan Umum, 7 orang perawat Unit Pelayanan Umum, 11 orang Dokter Penanggung Jawab Pasien 
(DPJP) integrasi, dan 3 orang perawat integrasi (RSGMP Unsoed, 2015). Hipotesis yang dikembangkan pada penelitian ini dijelaskan di kerangka konsep pada Gambar 1.

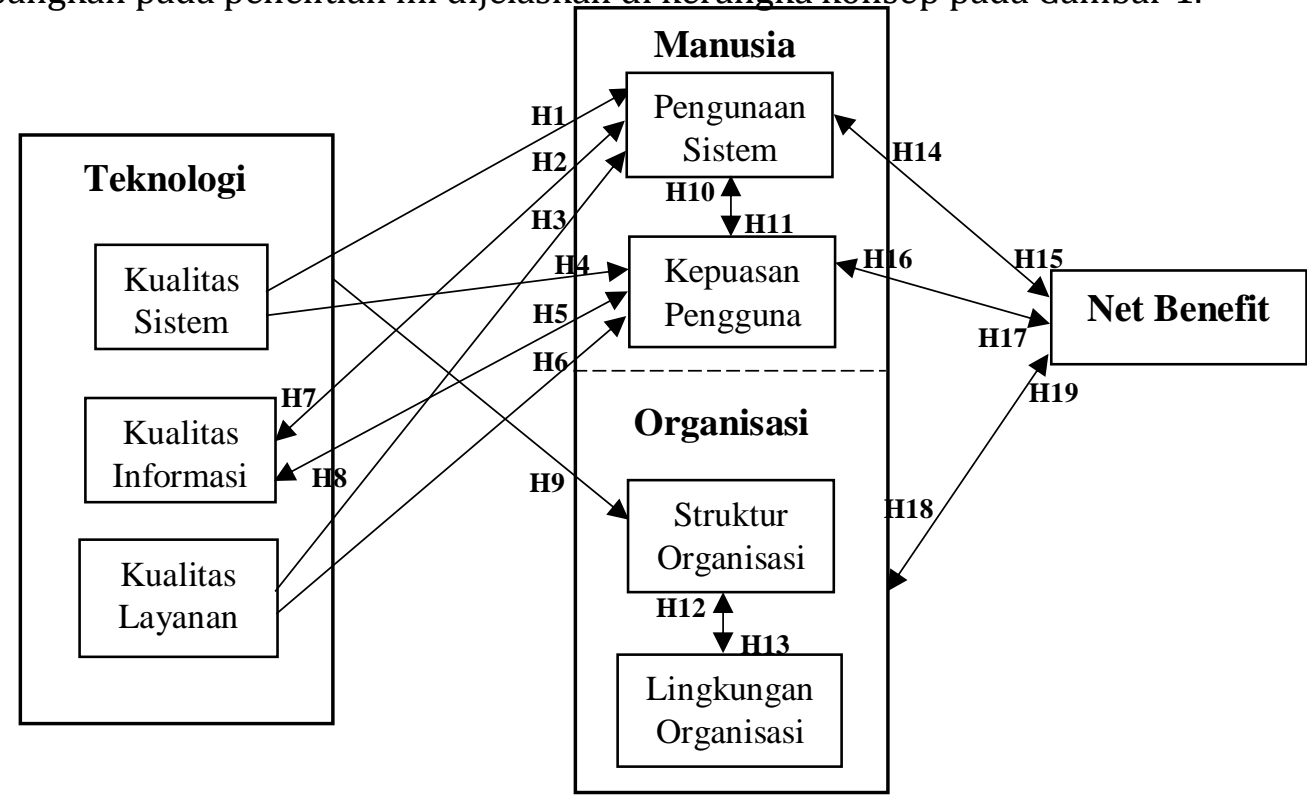

Gambar 1. Kerangka Konsep

Berdasarkan Gambar 1, hipotesis penelitian yang dikembangkan dalam metode HOT Fit ini adalah: (1) kualitas sistem memiliki pengaruh positif terhadap penggunaan sistem; (2) kualitas informasi memiliki pengaruh positif terhadap penggunaan sistem; (3) kualitas layanan memiliki pengaruh positif terhadap penggunaan sistem; (4) kualitas sistem memiliki pengaruh positif terhadap kepuasan pengguna; (5) kualitas informasi memiliki pengaruh positif terhadap kepuasan pengguna; (6) kualitas layanan memiliki pengaruh positif terhadap kepuasan pengguna; (7) penggunaan sistem memiliki pengaruh positif terhadap kualitas informasi; (8) kepuasan pengguna memiliki pengaruh positif terhadap kualitas informasi; (9) teknologi memiliki pengaruh positif terhadap struktur organisasi; (10) kepuasan pengguna memiliki pengaruh positif terhadap pengunaan sistem; (11) pengunaan sistem memiliki pengaruh positif terhadap kepuasan pengguna; (12) lingkungan organisasi memiliki pengaruh positif terhadap struktur organisasi; (13) struktur organisasi memiliki pengaruh positif terhadap lingkungan organisasi; (14) net benefit memiliki pengaruh positif terhadap penggunaan sistem; (15); penggunaan sistem memiliki pengaruh positif terhadap net benefit; (16) net benefit memiliki pengaruh positif terhadap kepuasan pengguna; (17) kepuasan pengguna memiliki pengaruh positif terhadap net benefit; (18) net benefit memiliki pengaruh positif terhadap organisasi; (19) organisasi memiliki pengaruh positif pengaruh terhadap net benefit.

\section{METODE PENELITIAN}

Jenis penelitian ini adalah penelitian analitik dengan pendekatan kuantitatif. Total populasi penelitian ini adalah seluruh petugas struktural dan staf yang berkaitan langsung dengan SIM farmasi yang berjumlah 43 orang. Metode pengumpulan data yang digunakan dalam penelitian ini adalah wawancara dengan instrumen berupa kuesioner dan lembar observasi. Kuesioner berisi pernyataan dari variabel Human yang terdiri dari penggunaan sistem dan kepuasan pengguna, variabel Organization yang terdiri dari struktur dan lingkungan organisasi, variabel Technology yang terdiri dari kualitas sistem, kualitas informasi, dan kualitas layanan, serta variabel Net benefit. Skala pengukuran yang digunakan dalam kuesioner ini skala Likert dengan menggunakan rentang skor 1-5. Teknik analisis data pada penelitian ini menggunakan program SPSS dimulai dari uji instrumen yaitu uji validitas dan realibilitas.

Uji validitas yang digunakan adalah korelasi Pearson. Teknik uji reliabilitas yang digunakan adalah teknis analisis Alpha Cronbach. Suatu kuesioner dikatakan reliabel apabila 
mempunyai alpha lebih besar dari 0,7. Uji asumsi klasik dilakukan dengan melakukan uji multikolineritas, uji heteroskedastisitas, dan uji normalitas. Cara mendeteksi adanya multikolineritas adalah dengan melihat nilai dari Tolerance dan Variance Inflasion Factor (VIF). Untuk mendeteksi adanya gejala heteroskedatisitas, yaitu ada atau tidaknya pola yang terjadi pada nilai residu pada model dalam penelitian ini menggunakan uji Glejser. Pengujian normalitas data menggunakan uji kolmogorov-smirnov. Pengujian hipotesis dilakukan dengan melakukan uji regresi.

\section{HASIL DAN PEMBAHASAN}

\section{Karakteristik Responden}

Hasil karakteristik responden berdasarkan usia terlihat bahwa responden di dominasi oleh kelompok usia 26-35 tahun, dan paling sedikit adalah kelompok usia lebih dari 55 tahun. Menurut Depkes RI (2009), kelompok umur 26-35 tahun merupakan kelompok umur dewasa awal. Pada kelompok umur ini diketahui merupakan usia produktif manusia dalam bekerja, dimana fungsi tubuh manusia sedang bekerja secara optimal termasuk daya ingatnya, sehingga RSGMP Unsoed banyak memperkerjakan pegawai dengan rentang usia ini. Sedangkan kelompok umur lebih dari 55 tahun merupakan kelompok umur lansia. Pada lansia banyak terjadi penurunan fungsi tubuh yang salah satunya adalah penurunan daya ingat (Riauwi dkk., 2014).

Responden berdasarkan jenis kelamin paling banyak adalah responden dengan jenis kelamin perempuan dibandingkan laki-laki. Hal ini terjadi karena kondisi pegawai yang ada di RSGMP Unsoed baik dokter, apoteker, perawat, maupun bidang lainnya yang dapat mengakses langsung SIM farmasi rumah sakit paling banyak adalah berjenis kelamin perempuan. Jumlah responden paling banyak berdasarkan pekerjaan adalah responden yang bekerja di RSGMP Unsoed sebagai Dokter Gigi Integrasi atau Dosen Penanggung Jawab Pasien. Hal ini dikarenakan kebutuhan atas dokter gigi integrasi yang memang cukup banyak untuk menjadi supervisor dari mahasiswa profesi atau mahasiswa co-ass, mengingat banyaknya mahasiswa profesi yang sedang menjalani pendidikan di klinik integrasi RSGMP Unsoed.

\section{Distribusi Jawaban Responden}

Hasil jawaban responden terbanyak berdasarkan kuesioner variabel human terkait penggunaan sistem menunjukkan bahwa pengguna tidak selalu menggunakan sistem SIM Farmasi terkomputerisasi dalam mengerjakan tugas-tugasnya, sebagian besar responden belum melakukan pelatihan penggunaan sistem sebelumnya, padahal responden masih banyak yang merasa belum memiliki keterampilan dalam mengoperasikannya dan sistem yang ada dirasa sulit digunakan. Pengguna juga merasa SIM farmasi yang ada belum membantu pengguna untuk menyelesaikan pekerjaannya dengan cepat. Hasil persepsi sebagian besar responden untuk variabel human terkait kepuasan pengguna menunjukkan bahwa SIM Farmasi dirasa belum membantu dalam mengelola informasi, tidak mempermudah pengguna dalam melakukan tugasnya, dan dirasa kurang dapat meningkatkan kinerja pengguna.

Berdasarkan data tersebut diketahui bahwa penggunaan sistem dan kepuasan pengguna SIM Farmasi di RSGMP Unsoed masih rendah. Hal ini harus diperhatikan oleh pihak rumah sakit sebagai penyelenggara sistem untuk dapat meningkatkan upaya dalam penerapan unsur human agar tingkat penggunaan sistem dapat meningkat intensitasnya dan kepuasan pengguna juga dapat meningkat. Salah satu cara yang dapat bermanfaat menanggapi keluhan yang ada yaitu dengan menyediakan pelatihan untuk pengguna agar pengguna lebih memahami sistem, tidak kesulitan dalam mengoperasikan sistem, dan lebih tertarik untuk selalu menggunakan sistem yang ada.

Hasil persepsi sebagian besar responden berdasarkan kuesioner variabel organization terkait struktur organisasi menunjukkan responden memiliki persepsi bahwa pimpinan belum menyediakan bantuan fasilitas yang mendukung pengguna dalam menerapkan SIM Farmasi terkomputerisasi, responden juga merasa bahwa pimpinan tidak mempertimbangkan latar belakang pendidikan calon pengguna sistem terlebih dahulu, namun responden menilai bahwa pimpinan telah memiliki komunikasi yang baik dengan para calon pengguna sistem tersebut. 
Fasilitas jaringan yang ada menurut sebagian responden juga belum cukup memadai. Hasil jawaban sebagian besar responden variabel organization terkait lingkungan organisasi menunjukkan responden memiliki persepsi belum mendapat dorongan dari pihak manajemen maupun teman sekerja untuk menggunakan SIM Farmasi dikomputer.

Responden juga merasa belum terdapat pihak IT yang aktif berkomunikasi dengan para pengguna. SIM Farmasi yang belum rutin digunakan ini juga membuat sistem yang ada tidak meningkatkan komunikasi data dan dinilai belum dapat menghemat waktu dalam penyajian informasi. Data yang ada menunjukkan sebagian besar responden menilai sistem yang ada belum memiliki layanan program bantuan berupa helpdesk support yang dapat membantu pengguna dalam penerapan sistem dan juga sistem tidak memiliki jaminan terhadap kualitas layanannya. Responden juga menilai bahwa divisi SIM yang ada belum memiliki rasa peduli atau empati dalam membantu pengguna dan belum bisa menyelesaikan masalah yang dihadapi oleh pengguna hingga selesai.

Hal-hal yang telah disebutkan diatas dapat diartikan bahwa kinerja organisasi yang ada saat ini masih belum baik. Kondisi yang terjadi di RSGMP Unsoed ini harus ditindaklanjuti oleh pihak rumah sakit sebagai penyelenggara sistem. Kinerja dari organisasi baik struktur maupun lingkungan organisasi harus lebih baik dalam mendukung keberhasilan penerapan sistem informasi yang ada dengan memberikan dorongan motivasi dan menyediakan fasilitas yang memadai. Komunikasi pimpinan yang dinilai sudah baik oleh para pengguna sistem harus dipertahankan dan terus ditingkatkan untuk membantu para pengguna sistem dalam menjalankan sistem tersebut.

Hasil jawaban responden terbanyak berdasarkan kuesioner variabel technology terkait kualitas sistem menunjukkan bahwa sebagian besar responden merasa sistem infrastruktur yang ada saat ini belum memadai, sistem masih sulit untuk dipelajari, sistem belum memiliki fasilitas petunjuk dalam penggunaannya, dan juga belum memiliki jaminan tidak error apabila diterapkan. SIM Farmasi yang ada saat ini juga dinilai belum dapat mempercepat dalam menyajikan informasi. Hal ini dapat diartikan bahwa kualitas sistem yang ada masih belum baik. Hasil tanggapan terbanyak responden variabel kualitas informasi menunjukkan sebagian besar responden merasa SIM Farmasi yang ada saat ini tidak dapat menyediakan informasi yang relevan, lengkap, akurat, dan juga belum mudah untuk dipahami.

Hal yang telah disebutkan diatas dapat diartikan bahwa kualitas informasi yang dihasilkan oleh sistem juga masih belum baik. Hasil tanggapan responden terbanyak variabel kualitas layanan menunjukkan sebagian besar responden menilai sistem yang ada belum memiliki layanan program bantuan berupa helpdesk support yang dapat membantu pengguna dalam penerapan sistem dan juga sistem tidak memiliki jaminan terhadap kualitas layanannya. Responden juga menilai bahwa divisi SIM yang ada belum memiliki rasa peduli atau empati dalam membantu pengguna dan belum bisa menyelesaikan masalah yang dihadapi oleh pengguna hingga selesai. Hal ini dapat diartikan bahwa kualitas layanan yang ada saat ini masih belum baik. Dari hasil jawaban responden mengenai kualitas sistem, kualitas informasi, dan kualitas layanan diketahui bahwa kualitas ketiganya masih belum baik, sehingga faktor teknologi ini harus diperbaiki dan dtingkatkan lagi kualitasnya.

SIM Farmasi yang ada harus dilengkapi kembali fitur sistemnya agar sitem dapat dimanfaatkan dan berguna bagi penggunanya. Hasil dari analisis statistik nilai beta menunjukkan bahwa kualitas sistem adalah bagian dari teknologi yang paling memiliki pengaruh besar terhadap tingkat penggunaan sistem, diikuti dengan kualitas layanan dan kualitas informasi. Hasil dari analisis statistik nilai beta menunjukkan bahwa kualitas layanan adalah bagian dari teknologi yang paling memiliki pengaruh besar terhadap tingkat kepuasan pengguna, diikuti dengan kualitas sistem dan kualitas informasi. Berdasarkan hal tersebut, maka perbaikan yang harus dilakukan RSGMP Unsoed dalam bidang teknologi dapat dimulai dari perbaikan kualitas sistem dan kualitas layanan yang memiliki pengaruh paling besar, lalu diikuti dengan perbaikan kualitas informasi.

Hasil uji validitas yang dilakukan pada seluruh variabel masing-masing memiliki nilai $r$ hitung lebih dari $r$ tabel 0,301. Hal tersebut menunjukkan seluruh item pertanyaan yang diajukan dalam penelitian adalah valid. Hasil koefisien reliabilitas seluruh variabel diketahui memiliki nilai 
Alpha Cronbach lebih besar dari 0,7. Maka dengan demikian seluruh pertanyaan pada masingmasing variabel dinyatakan reliabel. Hasil uji multikolineritas penelitian ini menunjukkan bahwa semua variabel menunjukkan nilai VIF $<10$ dan nilai tolerance $>0,1$. Hal ini menunjukkan bahwa pada penelitian ini tidak terdapat gejala multikolineritas dalam permodelan regresi. Hasil uji heteroskedastisitas diperoleh bahwa model regresi terbebas dari heteroskedastisitas karena seluruh variabel mempunyai nilai signifikansi menunjukkan nilai $>0,05$. Hasil uji normalitas pada penelitian menunjukkan nilai lebih besar dari 0,05 sehingga data dapat dikatakan memiliki distribusi normal.

\section{Kualitas sistem memiliki pengaruh positif terhadap penggunaan sistem}

Hasil analisis regresi untuk menguji hipotesis 1 pada penelitian ini menyatakan kualitas sistem berpengaruh positif terhadap penggunaan sistem. Hal ini menunjukkan bahwa semakin tinggi atau baik kualitas suatu sistem akan semakin tinggi juga tingkat penggunaan dari sistem tersebut untuk digunakan oleh pengguna. Hasil penelitian ini sejalan dengan hasil penelitian dari Krisbiantoro dkk. (2015) yang menyatakan bahwa kualitas sistem memiliki pengaruh terhadap penggunaan sistem yang berarti semakin meningkat kualitas sistem maka akan meningkatkan pula penggunaanya. Penelitian yang dilakukan oleh Bayu dan Izzati (2013) menyebutkan bahwa rumah sakit selaku penyedia sistem informasi diharapkan dapat terus melakukan perbaikan sistem guna meningkatkan kualitas dari sistem informasi.

McGill dkk. (2013) menyatakan bahwa setelah timbul persepsi atas kualitas sistem, maka persepsi ini akan berpengaruh terhadap penggunaan dan kepuasan pengguna akhir sistem. Persepsi kualitas sistem yang baik akan meningkatkan antusiasme penggunaannya, sedangkan kualitas sistem yang dirasa kurang baik seperti yang dirasakan oleh pengguna SIM Farmasi di RSGMP Unsoed akan menurunkan tingkat penggunaannya. Dari hasil statistik nilai beta, kualitas sistem diketahui merupakan unsur dari teknologi yang paling memiliki pengaruh terhadap penggunaan sistem. Maka dari itu perbaikan dari kualitas sistem adalah prioritas yang harus dilakukan RSGMP Unsoed jika ingin meningkatkan intensitas penggunaan sistem oleh pengguna.

\section{Kualitas informasi memiliki pengaruh positif terhadap penggunaan sistem}

Hasil analisis regresi untuk menguji hipotesis 2 pada penelitian ini menyatakan kualitas informasi berpengaruh positif terhadap penggunaan sistem. Hal ini menunjukkan bahwa semakin tinggi atau baik kualitas suatu informasi akan semakin tinggi juga tingkat penggunaan dari sistem tersebut untuk digunakan oleh pengguna. Hasil penelitian ini sejalan dengan penelitian Nurlani dan Permana (2017) yang menyebutkan bahwa kualitas suatu informasi dari hasil sistem yang ada berpengaruh signifikan terhadap penggunaan sistem informasi tersebut. Menurut Yusof dkk. (2008), kualitas dari suatu informasi dinilai dari tingkat keakuratan dan tingkat relevan data informasinya. Dikatakan akurat apabila informasi tersebut bebas dari kesalahan dan tidak bias. Sedangkan informasi dikatakan relevan apabila informasi tersebut mempunyai manfaat untuk penggunanya.

Relevansi informasi untuk masing-masing orang satu dengan yang lainnya adalah berbeda-beda. Sehingga jika kualitas informasi pada suatu sistem sangat bagus atau dinilai memiliki kualitas yang baik maka akan semakin bisa menarik pengguna untuk menggunakan sistem tersebut. Hasil penelitian terhadap kualitas informasi menurut pengguna di SIM Farmasi Unsoed menghasilkan nilai yang rendah, sehingga penggunaan sistem juga masih rendah penerapannya. Dari hasil statistik nilai beta, kualitas informasi diketahui merupakan unsur dari teknologi yang memiliki pengaruh paling kecil terhadap penggunaan sistem apabila dibandingkan dengan pengaruh dari kualitas sistem dan kualitas layanan. Namun perbaikan dari kualitas informasi tetap harus dilakukan pihak RSGMP Unsoed untuk meningkatkan intensitas penggunaan sistem oleh pengguna.

\section{Kualitas layanan memiliki pengaruh positif terhadap penggunaan sistem}

Hasil analisis regresi untuk menguji hipotesis 3 pada penelitian ini menyatakan kualitas layanan berpengaruh positif terhadap penggunaan sistem. Hal ini menunjukkan bahwa semakin tinggi atau baik kualitas layanan suatu sistem akan semakin tinggi juga tingkat penggunaan dari 
sistem tersebut untuk digunakan oleh pengguna. Hasil penelitian ini sejalan dengan penelitian Kodarisman dan Nugroho (2013) juga penelitian Krisbiantoro dkk. (2015), dimana hasil pengujiannya menunjukkan bahwa kualitas layanan sistem (service quality) memiliki pengaruh positif terhadap penggunaan sistem tersebut. Menurut Akhiroh (2008), kualitas layanan dapat diartikan sebagai sesuatu yang berhubungan dengan terpenuhinya kebutuhan pengguna, layanan dapat dikatakan berkualitas apabila dapat menyediakan produk dan pelayanan yang sesuai dengan kebutuhan dan keinginan pengguna.

Kualitas layanan sistem informasi manajemen berfokus pada keseluruhan dukungan yang diterima oleh service provider sistem atau teknologi (Musrifah, 2017). Hasil penelitian di RSGMP Unsoed menunjukkan bahwa kualitas layanan sistem masih belum baik dirasakan oleh pengguna, pengguna sistem masih merasa belum mendapat dukungan dari penyedia jasa layanan dalam penerapan sistem tersebut di instalasi farmasi, hal ini yang akhirnya membuat para pengguna sistem tidak tertarik menggunakan sistem informasi manajemen farmasi secara berkelanjutan. Dari hasil statistik nilai beta, kualitas layanan diketahui merupakan unsur dari teknologi yang memiliki pengaruh kedua paling besar terhadap penggunaan sistem setelah pengaruh dari kualitas sistem. Perbaikan dari kualitas layanan tetap harus dilakukan pihak RSGMP Unsoed sebagai upaya untuk terus meningkatkan angka penggunaan sistem.

\section{Kualitas sistem memiliki pengaruh positif terhadap kepuasan pengguna}

Hasil analisis regresi untuk menguji hipotesis 4 pada penelitian ini menyatakan kualitas sistem berpengaruh positif terhadap kepuasan pengguna. Hal ini menunjukkan bahwa semakin tinggi atau baik kualitas suatu sistem, akan semakin tinggi juga tingkat kepuasan terhadap sistem yang dirasakan oleh pengguna. Hasil penelitian ini sejalan dengan hasil penelitian dari Poluan dkk. (2014) yang menyatakan bahwa peningkatan dan perbaikan terhadap sistem informasi dan stabilitasnya oleh penyedia layanan akan meningkatkan penggunaan sistem dan berujung pada kepuasan pengguna. Kepuasan para pengguna mencerminkan seberapa jauh pengguna percaya pada suatu sistem informasi yang disediakan dapat memenuhi kebutuhan informasi mereka (Guimaraes dkk., 2003). Pernyataan DeLone dan McLean (2003) juga menunjukkan bahwa kualitas sistem berpengaruh terhadap kepuasan penggunanya.

Hasil penelitian ini diperkuat oleh pernyataan Sari dkk. (2016) yang menyebutkan bahwa jika kualitas sistem kurang baik seperti adanya kesulitan teknis yang mengganggu, infrastruktur sistem kurang memadai dan sistem mudah error, dapat menurunkan tingkat kepuasan pengguna. Keluhan-keluhan tersebut juga dirasakan oleh pengguna SIM Farmasi di RSGMP Unsoed sehingga diketahui tingkat kepuasan pengguna sistem menjadi rendah. Dari hasil statistik nilai beta, kualitas sistem diketahui merupakan unsur dari teknologi yang memiliki pengaruh kedua paling besar terhadap kepuasan pengguna setelah pengaruh dari kualitas layanan. Untuk meningkatkan kepuasan pengguna terhadap sistem yang ada, perlu dilakukan perbaikan dari kualitas sistem dengan menindaklanjuti keluhan-keluhan yang ada di SIM Farmasi RSGMP Unsoed.

\section{Kualitas informasi memiliki pengaruh positif terhadap kepuasan pengguna}

Hasil analisis regresi untuk menguji hipotesis 5 pada penelitian ini menyatakan kualitas informasi berpengaruh positif terhadap kepuasan pengguna. Hal ini menunjukkan bahwa semakin tinggi atau baik kualitas suatu informasi, akan semakin tinggi juga tingkat kepuasan terhadap sistem yang dirasakan oleh pengguna. Hasil penelitian ini sejalan dengan penelitian Yusof dkk. (2008) yang menyatakan bahwa kualitas informasi merupakan faktor yang paling berpengaruh terhadap kepuasan pengguna. Semakin tinggi kualitas informasi yang dihasilkan suatu sistem informasi, akan semakin meningkatkan kepuasan pemakai. Jika pemakai sistem informasi meyakini bahwa kualitas informasi yang dihasilkan dari sistem yang digunakan baik, mereka akan merasa puas menggunakan sistem tersebut (Istianingsih dan Wijanto, 2008).

Penelitian Putra dan Alfian (2016) juga membuktikan bahwa kualitas informasi berpengaruh positif terhadap kepuasan pengguna akhir. Semakin lengkap, akurat, dan relevan informasi yang tersedia, maka akan semakin tinggi pula tingkat kepuasan pengguna terhadap sistem informasi secara keseluruhan. Hasil penelitian mengenai data penilaian kualitas informasi dari SIM Farmasi RSGMP Unsoed menurut pengguna menunjukkan hasil nilai yang rendah 
sehingga menurunkan kepercayaan pengguna dan menyebabkan rendahnya kepuasan pengguna. Dari hasil statistik nilai beta, kualitas informasi diketahui merupakan unsur dari teknologi yang memiliki pengaruh terkecil terhadap penggunaan sistem apabila dibandingkan dengan kualitas sistem dan kualitas layanan. Namun perbaikan dari kualitas informasi tetap harus dilakukan pihak RSGMP Unsoed sebagai upaya untuk terus meningkatkan kepuasan dari para pengguna.

\section{Kualitas layanan memiliki pengaruh positif terhadap kepuasan pengguna}

Hasil analisis regresi untuk menguji hipotesis 6 pada penelitian ini menyatakan kualitas layanan berpengaruh positif terhadap kepuasan pengguna. Hal ini menunjukkan bahwa semakin baik kualitas layanan suatu sistem informasi, akan semakin tinggi juga tingkat kepuasan pengguna terhadap sistem. Hasil penelitian ini sejalan dengan penelitian Yessy dkk. (2016) yang menyatakan bahwa semakin tinggi kualitas layanan, maka akan semakin tinggi kepuasan pengguna. Hal ini mengindikasikan bahwa kualitas pelayanan sistem informasi yang semakin baik akan mempengaruhi peningkatan kepuasan pengguna. Apabila pengguna sistem informasi merasakan bahwa kualitas pelayanan yang diberikan oleh penyedia program aplikasi baik, maka pengguna akan cenderung untuk merasa puas untuk menggunakan sistem tersebut.

Hasil penelitian ini konsisten dengan hasil penelitian sebelumnya yang dilakukan oleh Lestari dkk. (2013) yang mengemukakan bahwa kualitas pelayanan secara signifikan berpengaruh terhadap kepuasan pengguna sistem informasi dimana kualitas pelayanan mencerminkan sejauh mana penyedia sistem dapat diandalkan, bertanggungjawab, dan memiliki empati kepada penggunanya. Pengguna SIM Farmasi di RSGMP Unsoed merasa bahwa kualitas layanan sistem informasi yang ada masih belum baik, sehingga pengguna cenderung merasa belum puas terhadap sistem informasi tersebut. Dari hasil statistik nilai beta, kualitas layanan diketahui merupakan unsur dari teknologi yang paling memiliki pengaruh terhadap kepuasan pengguna. Maka dari itu perbaikan dan peningkatan dari kualitas layanan adalah prioritas yang harus dilakukan RSGMP Unsoed jika ingin meningkatkan kepuasan pengguna SIM Farmasi.

\section{Penggunaan sistem memiliki pengaruh positif terhadap kualitas informasi}

Hasil analisis regresi untuk menguji hipotesis 7 pada penelitian ini menyatakan penggunaan sistem berpengaruh positif terhadap kualitas informasi. Hal ini menunjukkan bahwa semakin baik suatu sistem informasi diterapkan, akan semakin baik kualitas informasi yang dihasilkan. Hasil penelitian ini sesuai dengan penelitian Jansen dkk. (2018) dan Evania dkk. (2016) yang menunjukkan hasil bahwa pengaruh antara penggunaan sistem informasi dengan kualitas informasi adalah semakin besar penggunaan teknologi sistem informasi maka kualitas informasi yang dihasilkan akan semakin bagus. Dengan adanya penggunaan sistem informasi, maka akan memberikan dampak positif terhadap instansi dan memberikan keuntungan karena penggunaan teknologi informasi tersebut akan membantu dalam memperbaiki kualitas informasi.

Penggunaan sistem informasi, dalam hal ini dengan bantuan teknologi komputer, dapat membantu pengguna bekerja lebih efektif, efisien, dan menghasilkan infromasi data yang berkualitas. Hasil penelitian-penelitian ini sejalan dengan teori yang dinyatakan oleh Romney (2006), yang menyebutkan bahwa penggunaan sistem informasi mempunyai dampak yang sangat besar dalam kualitas informasi. Bodnar (2003), menyatakan bahwa suatu keberhasilan sistem dalam menghasilkan sebuah informasi yang berkualitas sangat ditentukan pada faktor perilaku dan individu pengguna seperti penggunaannya terhadap sistem informasi tersebut. Penggunaan SIM Farmasi di RSGMP Unsoed masih rendah dalam penerapannya oleh pengguna karena tidak didukung dengan teknologi informasi yang baik, sehingga kualitas informasi yang dihasilkan juga belum baik.

\section{Kepuasan pengguna memiliki pengaruh positif terhadap kualitas informasi}

Hasil analisis regresi untuk menguji hipotesis 8 pada penelitian ini menyatakan kepuasan pengguna berpengaruh positif terhadap kualitas informasi. Hal ini menunjukkan bahwa semakin puas pengguna terhadap suatu sistem, maka akan semakin baik kualitas informasi yang dihasilkan. Hasil penelitian ini sesuai dengan penelitian Santoso (2012) yang menemukan bahwa 
kepuasan pengguna akan berpengaruh terhadap kualitas informasi yang diperoleh dari sistem. Penelitian Darwanis dan Mahyani (2009) juga mengemukakan bahwa kepuasan pengguna sistem informasi merupakan indikator keberhasilan penerapan sistem informasi berupa kualitas informasi. Pemanfaatan sistem informasi akan mempengaruhi kepuasan pengguna yang pada akhirnya akan meningkatkan keakuratan data informasi atau kualitas dari suatu informasi.

Yusof dkk. (2008) dan Erimalata (2016) menyatakan bahwa terdapat hubungan dua arah (resiprokal) antara kepuasan pengguna dengan kualitas informasi. Menurut Putra dan Alfian (2016), kepuasan pengguna (user satisfaction) merupakan respon dan umpan balik pengguna terhadap penggunaan output sebuah perangkat lunak. Sikap pengguna terhadap perangkat lunak merupakan kriteria subyektif mengenai seberapa puas pengguna terhadap sistem yang digunakannya. Tingkat kepuasan pengguna SIM Farmasi di RSGMP Unsoed terhadap sistem dinilai rendah, sehingga hal ini mempengaruhi tingkat kualitas informasi yang dihasilkan oleh sistem yang berjalan juga masih rendah.

\section{Teknologi memiliki pengaruh positif terhadap struktur organisasi}

Hasil analisis regresi untuk menguji hipotesis 9 pada penelitian ini menyatakan teknologi berpengaruh positif terhadap struktur organisasi. Hal ini menunjukkan bahwa semakin baik teknologi yang ada pada suatu sistem informasi, maka akan semakin jelas dan baik pula struktur organisasi yang ada. Hasil penelitian ini sesuai dengan penelitian Perwira (2016) yang menyebutkan bahwa unsur teknologi mempengaruhi unsur organisasi yaitu struktur organisasi. Musrifah (2017) menambahkan bahwa struktur organisasi yang baik dapat dilihat dari manajemen, komunikasi dan dukungan yang diterima dari organisasinya. Struktur organisasi yang baik dapat memisahkan tanggung jawab fungsional secara tegas untuk mendukung keberhasilan sistem informasi yang diterapkan (Kazemi dkk., 2016).

Menurut Erlirianto dkk. (2015), unsur teknologi dapat mempengaruhi struktur sebuah organisasi agar dapat dengan jelas melaksanakan tugasnya masing-masing untuk menjamin keberhasilan penyelenggaraan sistem informasi di suatu organisasi. Teknologi yang digunakan akan mempengaruhi organisasi dalam menyusun strategi dan merencanakan rangkaian pengendalian yang akan dilakukan dalam mencapai tujuan organisasi. Semakin jelas dan baik kualitas teknologi suatu sistem informasi, maka semakin jelas pula tugas dari setiap elemen di struktur organisasi guna mendukung berjalannya sistem. Unsur teknologi di RSGMP Unsoed dinilai pengguna masih belum cukup baik dan jelas sehingga struktur organisasi yang ada untuk mengurus dan mendukung sistem ini di RSGMP Unsoed masih belum memiliki tugas masingmasing yang jelas.

\section{Kepuasan pengguna memiliki pengaruh positif terhadap penggunaan sistem}

Hasil analisis regresi untuk menguji hipotesis 10 pada penelitian ini menyatakan kepuasan pengguna berpengaruh positif terhadap penggunaan sistem. Hal ini menunjukkan bahwa semakin tinggi kepuasan pengguna terhadap sistem informasi yang ada, maka akan semakin tinggi tingkat penggunaan sistem tersebut. Hasil penelitian ini sesuai dengan penelitian Gursel dkk. (2014) dan Sari dkk. (2016) yang menyatakan bahwa tingkat kepuasan berpengaruh secara langsung terhadap penggunaan sistem. Jika SIM dirasa memuaskan maka tingkat penggunaannya akan semakin sering. Penelitian Bayu dan Izzati (2013) juga menyatakan bahwa kepuasan pengguna setelah menggunakan suatu software akan semakin meningkatkan kebutuhan pemakai dan intensitas penggunaan terhadap software.

Menurut Imam (2009), kepuasan pengguna dipengaruhi oleh karakteristik personal dan dapat dihubungkan dengan persepsi manfaat (usefulness) terhadap sistem informasi. Penggunaan sistem informasi mengacu pada seberapa sering pengguna menggunakan sistem informasi. Semakin sering pengguna memakai sistem informasi, biasanya diikuti oleh semakin banyak tingkat pembelajaran (degree of learning) yang didapat pengguna mengenai sistem informasi. Apabila pengguna sistem merasa puas dan terbantu dengan adanya sistem, maka pengguna akan terus menerus menggunakan sistem tersebut. Kepuasan pengguna terhadap sistem yang ada di instalasi farmasi RSGMP Unsoed masih rendah, sehingga tingkat penggunaan sistem tersebut juga masih rendah. 


\section{Penggunaan sistem memiliki pengaruh positif terhadap kepuasan pengguna}

Hasil analisis regresi untuk menguji hipotesis 11 pada penelitian ini menyatakan penggunaan sistem berpengaruh positif terhadap kepuasan pengguna. Hal ini menunjukkan bahwa semakin tinggi angka penggunaan suatu sistem informasi, maka akan semakin tinggi tingkat kepuasan penggunanya. Hasil penelitian ini sesuai dengan penelitian Poluan dkk. (2014) yang menyatakan bahwa adanya peningkatan penggunaan sistem oleh pemakai sistem yang biasanya dibarengi dengan peningkatan dan perbaikan terhadap sistem dan stabilitasnya oleh penyedia layanan akan berujung pada kepuasan pengguna. Apabila pengguna sistem merasakan ada manfaat yang didapatkan dari penggunaan sistem informasi, akan menimbulkan perilaku penggunaan sistem secara terus menerus untuk membantu menyelesaikan tugas dan pekerjaannya dan akan menimbulkan kepuasan pengguna sistem tersebut (Rozanda dan Masriana, 2017).

Menurut Diana dan Setiawati (2010), jika seseorang percaya bahwa dengan menggunakan sistem mampu meningkatkan kinerja sehingga tingkat penggunaan sistem menjadi tinggi, maka akan semakin meningkatkan kepercayaan dan kepuasan bagi pengguna sistem informasi tersebut. Tingkat penggunaan SIM Farmasi di RSGMP Unsoed yang rendah menunjukkan bahwa pengguna kurang percaya bahwa sistem tersebut dapat meningkatkan kinerja pengguna, sehingga kepuasan pengguna terhadap sistem juga menjadi rendah. Tingkat penggunaan sistem yang rendah juga disebabkan oleh banyaknya kendala yang dialami oleh pengguna saat akan menggunakan sistem informasi tersebut.

\section{Lingkungan organisasi memiliki pengaruh positif terhadap struktur organisasi}

Hasil analisis regresi untuk menguji hipotesis 12 pada penelitian ini menyatakan lingkungan organisasi berpengaruh positif terhadap struktur organisasi. Hal ini menunjukkan bahwa semakin baik lingkungan organisasi yang ada disekitar untuk mewujudkan sistem informasi, maka akan semakin jelas dan baik pula struktur organisasi yang ada. Hasil penelitian ini sesuai dengan penelitian Sari dkk. (2016) yang menunjukkan hasil bahwa lingkungan organisasi memiliki efek signifikan terhadap struktur organisasi. Erlirianto (2015) menunjukkan bahwa lingkungan organisasi menunjukkan pengaruh signifikan terhadap penyelenggaraan sistem informasi. Regulasi yang berlaku di sebuah organisasi akan mempengaruhi rencana pengembangan sistem informasi manajemen dan kebijakan yang diberlakukan oleh organisasi tersebut dalam penerapan sistem informasinya.

Hal ini akhirnya akan mempengaruhi tatanan struktur organisasi agar masing-masing elemen dapat menjalankan tugasnya untuk keberhasilan penyelenggaraan sistem. Menurut Bayu dan Izzati (2013), dorongan dari lingkungan organisasi secara signifikan dapat memberikan motivasi untuk meningkatkan kinerja anggota organisasi dan penyedia sistem. Hal ini dapat dicapai melalui strategi dan manajemen seperti dukungan pemimpin, kerja tim, dan komunikasi efektif yang dibentuk dengan melibatkan peran dan kemampuan karyawan. Persepsi pengguna terhadap lingkungan organisasi yang ada di RSGMP Unsoed dinilai masih kurang baik dalam mendukung penyelenggaraan SIM Farmasi, sehingga persepsi pengguna terhadap struktur organisasi yang ada juga kurang baik.

\section{Struktur organisasi memiliki pengaruh positif terhadap lingkungan organisasi}

Hasil analisis regresi untuk menguji hipotesis 13 pada penelitian ini menyatakan struktur organisasi berpengaruh positif terhadap lingkungan organisasi. Hal ini menunjukkan bahwa semakin baik dan jelas struktur organisasi yang ada, maka akan semakin baik pula lingkungan organisasinya. Hasil penelitian ini sesuai dengan penelitian Perwira (2016) dan Krisbiantoro (2015) yang menyatakan bahwa struktur organisasi (structure) berpengaruh positif dan signifikan terhadap lingkungan organisasi (environment). Penelitian Yuliasari (2014) juga menyebutkan bahwa semakin baik struktur organisasi maka akan berpengaruh positif juga pada kondisi lingkungan organisasinya.

DeLone dan McLean (2003) telah menguji secara empiris bahwa kinerja struktur organisasi dalam menyelenggarakan sistem infromasi mempunyai pengaruh positif terhadap 
lingkungan suatu organisasi contohnya terhadap manajemen organisasi. Sehingga sebuah organisasi harus terus berupaya melakukan evaluasi terhadap struktur organisasi yang ada untuk dapat terus meningkatkan keberhasilan sistem. Struktur organisasi dalam mendukung penyelenggaraan SIM Farmasi di RSGMP Unsoed dinilai pengguna masih belum baik. Hal tersebut dikarenakan komunikasi dan bantuan fasilitas dari pimpinan manajemen dinilai pengguna masih kurang, sehingga pengguna juga menilai bahwa pihak lainnya di lingkungan organisasi yang terlibat dalam penyeleggaraan sistem informasi juga menjadi kurang mendukung keberhasilan sistem yang ada.

\section{Net benefit memiliki pengaruh positif terhadap penggunaan sistem}

Hasil analisis regresi untuk menguji hipotesis 14 pada penelitian ini menyatakan bahwa net benefit berpengaruh positif terhadap penggunaan sistem. Hal ini menunjukkan bahwa semakin bermanfaat sebuah sistem bagi pengguna, maka akan semakin tinggi tingkat penggunaan sistem tersebut. Hasil penelitian ini sesuai dengan penelitian Betri (2017) yang menyatakan bahwa net benefit mempengaruhi system use secara langsung. Hal ini berarti semakin tinggi manfaat yang dirasakan pengguna dalam menggunakan sistem informasi manajemen yang ada maka semakin tinggi juga niat pengguna dalam menggunakan sistem informasi manajemen tersebut. Net benefit didapat dengan mengukur hasil pemanfaatan dari sistem informasi (Groho dkk., 2014).

Menurut Erimalata (2016), net benefit merupakan manfaat yang diperoleh dari sistem yang dapat diukur dari manfaat sistem secara langsung contohnya dari informasi yang dihasilkan oleh sistem tersebut maupun dari manfaat secara tidak langsung seperti dampak pada kinerja, efisiensi dan efektifitas kegiatan organisasi. Dari hasil penelitian pada persepsi pengguna SIM Farmasi RSGMP Unsoed terhadap net benefit diketahui bahwa para pengguna belum merasakan manfaat dari sistem informasi yang sudah ada. Karena pengguna merasa sistem yang ada kurang membantu dalam menyelesaikan tugasnya menjadi efetif dan efisisen, maka kebanyakan pengguna kurang berniat menggunakan sistem yang ada sehingga tingkat penggunaan sistem menjadi rendah.

\section{Penggunaan sistem memiliki pengaruh positif terhadap net benefit}

Hasil analisis regresi untuk menguji hipotesis 15 pada penelitian ini menyatakan bahwa penggunaan sistem berpengaruh positif terhadap net benefit. Hal ini menunjukkan bahwa semakin tinggi tingkat penggunaan sebuah sistem, maka semakin bermanfaat sistem tersebut bagi pengguna. Hasil penelitian ini sesuai dengan penelitian Nurlani dan Permana (2017) dan Evania dkk. (2016) yang menyatakan bahwa tingginya niat perilaku pengguna untuk penggunaan sistem terbukti secara empiris berpengaruh signifikan terhadap net benefits (manfaat-manfaat bersih) yang didapat. Dengan kata lain, intensitas pemakaian sistem memiliki pengaruh terhadap manfaat yang dihasilkan oleh suatu sistem.

Penelitian McGill dkk. (2013) juga menemukan bahwa semakin baik sistem dan output sistem yang diberikan, akan menyebabkan pengguna tidak merasa enggan untuk melakukan pemakaian kembali dan mengambil manfaat dari sistem. Tingkat penggunaan sistem informasi oleh pengguna di instalasi farmasi RSGMP Unsoed menunjukkan hasil yang rendah, sehingga manfaat yang didapatkan oleh pengguna dari sistem juga menjadi rendah. Dari hasil statistik nilai beta, penggunaan sistem diketahui merupakan unsur human yang paling memiliki pengaruh terhadap net benefit. Maka dari itu peningkatan angka penggunaan sistem adalah prioritas yang harus diperhatikan jika ingin meningkatkan persepsi pengguna terhadap net benefit.

\section{Net benefit memiliki pengaruh positif terhadap kepuasan pengguna}

Hasil analisis regresi untuk menguji hipotesis 16 pada penelitian ini menyatakan bahwa net benefit berpengaruh positif terhadap kepuasan pengguna. Hal ini menunjukkan bahwa semakin tinggi manfaat yang dirasakan pengguna dari sebuah sistem, maka semakin tinggi pula kepuasan pengguna terhadap sistem tersebut. Hasil penelitian ini sesuai dengan penelitian Hanadia (2017) yang menunjukkan hasil bahwa manfaat sistem berpengaruh signifikan dengan 
kepuasan pemakainya. Yang berarti semakin baik sistem yang diterapkan pada manusia maka semakin bermanfaat sebuah sistem dan pengguna akan semakin puas menggunakannya.

Menurut Westerling dkk. (2011), net benefits (manfaat-manfaat bersih) adalah suatu rangkaian kesatuan dari entitas individual sampai keseluruhan yang dapat memberikan dampak (impact) bagi aktivitas sistem informasi. Penelitian Gursel dkk. (2014) juga menunjukkan hasil bahwa tingginya derajat manfaat yang diperoleh dari sebuah sistem informasi mengakibatkan pemakai akan lebih puas. Penelitian terhadap persepsi net benefit pada pengguna SIM Farmasi di RSGMP Unsoed menunjukkan hasil bahwa pengguna merasa sistem yang ada kurang memberikan manfaat dan kurang membantu pengguna dalam menyelesaikan tugas, sehingga hal ini menyebabkan tingkat kepuasan pengguna terhadap sistem juga menjadi rendah.

\section{Kepuasan pengguna memiliki pengaruh positif terhadap net benefit}

Hasil analisis regresi untuk menguji hipotesis 17 pada penelitian ini menyatakan bahwa kepuasan pengguna berpengaruh positif terhadap net benefit. Hal ini menunjukkan bahwa semakin tinggi kepuasan pengguna terhadap sistem, maka semakin tinggi juga manfaat yang dirasakan pengguna dari sistem tersebut. Hasil penelitian ini sesuai dengan penelitian Abdau (2018) dan Santoso (2012) yang menunjukkan hasil bahwa terdapat hubungan searah (positif) antara kepuasan pengguna terhadap net benefit. Menurut Prasetyowati dan Kushartanti (2018), kepuasan merupakan respon dan umpan balik yang dimunculkan pengguna setelah memakai sistem informasi.

Penelitian terhadap kepuasan pengguna SIM Farmasi di RSGMP Unsoed menunjukkan hasil bahwa pengguna masih belum merasa puas terhadap sistem, sehingga hal ini menyebabkan pengguna merasa bahwa manfaat yang dirasakan dari sistem informasi yang ada juga masih rendah. Dari hasil statistik nilai beta, kepuasan pengguna sistem diketahui merupakan unsur dari human yang memiliki pengaruh terbesar kedua terhadap net benefit setelah penggunaan sistem. Namun upaya-upaya untuk meningkatan kepuasan pengguna terhadap sistem yang ada harus terus dilakukan pihak RSGMP Unsoed jika ingin meningkatkan persepsi pengguna terhadap net benefit dari sistem.

\section{Net benefit memiliki pengaruh positif terhadap organisasi}

Hasil analisis regresi untuk menguji hipotesis 18 pada penelitian ini menyatakan bahwa net benefit berpengaruh positif terhadap organisasi. Hal ini menunjukkan bahwa semakin tinggi net benefit atau manfaat yang dirasakan pengguna dari sebuah sistem, maka semakin baik organisasi yang ada. Hasil penelitian ini sesuai dengan penelitian Groho dkk. (2014) yang menemukan hasil apabila sebuah sistem informasi dinilai kurang memberikan manfaat, maka kinerja organisasi penyelenggara sistem juga akan dinilai kurang baik, sehingga diperlukan pembenahan dari organisasi tersebut untuk lebih dapat meningkatkan manfaat untuk penggunanya (Rozanda dan Masriana, 2017).

Menurut Dwibarto (2017), manfaat yang hendak diperoleh dari penggunaan sistem informasi manajemen adalah pengguna dapat merasa terbantu untuk menyelesaikan tugas, mendapatkan informasi data yang akurat, meningkatkan kinerja organisasi, mendukung visi misi organisasi, dan juga membantu dalam pengambilan keputusan. Pengguna SIM Farmasi di RSGMP Unsoed merasa belum mendapatkan manfaat dari adanya sistem informasi di instalasi farmasi tersebut, hal ini membuat persepsi penilaian pengguna terhadap organisasi penyelenggara sistem yang dalam hal ini ialah manajemen di instalasi farmasi RSGMP Unsoed juga belum baik.

\section{Pengaruh organisasi terhadap net benefit}

Analisis regresi untuk menguji hipotesis 19 menunjukkan hasil bahwa H19 yang menyatakan organisasi berpengaruh positif terhadap net benefit ditolak. Hasil pada penelitian ini menyatakan bahwa organisasi tidak memiliki pengaruh terhadap net benefit. Hasil penelitian ini sesuai dengan penelitian Hendra dkk. (2015) yang menyatakan bahwa organisasi tidak dapat secara langsung meningkatkan persepsi pengguna sistem terhadap manfaat atau net benefit. Penelitian Betri (2017) juga menjelaskan bahwa dorongan dari organisasi secara signifikan hanya dapat memberikan motivasi pengguna untuk menggunakan sistem. 
Setelah pengguna termotivasi untuk menggunakan sistem, selanjutnya baru akan dapat meningkatkan persepsi kebermanfaatan (net benefit) dan faktor teknologi tetap harus dikembangkan dan ditingkatkan kualitasnya. Hasil penelitian persepsi pengguna terhadap organisasi penyelenggara SIM Farmasi di RSGMP Unsoed dinilai kurang memfasilitasi penyelenggaran sistem yang diterapkan. Sistem informasi yang ada juga dinilai kurang bermanfaat. Namun pada penelitian terhadap SIM Farmasi RSGMP Unsoed ini organisasi tidak dapat dikatakan langsung bisa mempengaruhi net benefit, karena harus melewati faktor pendukung seperti tingkat penggunaan sistem, dan harus diperkuat dengan faktor teknologi.

\section{KESIMPULAN}

Kesimpulan yang dapat diambil dari penelitian ini adalah: (1) kualitas sistem memiliki pengaruh positif terhadap penggunaan sistem; (2) kualitas informasi memiliki pengaruh positif terhadap penggunaan sistem; (3) kualitas layanan memiliki pengaruh positif terhadap penggunaan sistem; (4) kualitas sistem memiliki pengaruh positif terhadap kepuasan pengguna; (5) kualitas informasi memiliki pengaruh positif terhadap kepuasan pengguna; (6) kualitas layanan memiliki pengaruh positif terhadap kepuasan pengguna; (7) penggunaan sistem memiliki pengaruh positif terhadap kualitas informasi; (8) kepuasan pengguna memiliki pengaruh positif terhadap kualitas informasi; (9) teknologi memiliki pengaruh positif terhadap struktur organisasi; (10) kepuasan pengguna memiliki pengaruh positif terhadap pengunaan sistem; (11) pengunaan sistem memiliki pengaruh positif terhadap kepuasan pengguna; (12) lingkungan organisasi memiliki pengaruh positif terhadap struktur organisasi; (13) struktur organisasi memiliki pengaruh positif terhadap lingkungan organisasi; (14) net benefit memiliki pengaruh positif terhadap penggunaan sistem; (15); penggunaan sistem memiliki pengaruh positif terhadap net benefit; (16) net benefit memiliki pengaruh positif terhadap kepuasan pengguna; (17) kepuasan pengguna memiliki pengaruh positif terhadap net benefit; (18) net benefit memiliki pengaruh positif terhadap organisasi; (19) organisasi tidak memiliki pengaruh terhadap net benefit.

Berdasarkan hasil analisis dan kesimpulan, implikasi atau manfaat dari penelitian ini yaitu RSGMP Unsoed dapat lebih mengoptimalkan penerapan ilmu manajemen yang ada dengan memperhatikan unsur human seperti menyediakan pelatihan untuk pengguna. RSGMP Unsoed diharapkan dapat lebih meningkatkan dan memperbaiki kinerja organisasi dengan memberikan dorongan motivasi kepada pengguna. RSGMP Unsoed juga dapat lebih meningkatkan mutu dan kualitas teknologi baik kualitas sistem, kualitas informasi maupun kualitas layanan dari sistem agar sistem dapat berguna bagi pengguna. Saran yang dapat diberikan untuk penelitian selanjutnya adalah pengembangan penelitian dapat dengan dilakukan penelitian lebih lanjut mengenai evaluasi sistem informasi manajemen rumah sakit (SIM RS) di RSGMP Unsoed secara keseluruhan. Penelitian lebih lanjut untuk mencari tahu penyebab hipotesis yang ditolak yaitu hipotesis pengaruh organisasi terhadap net benefit juga dapat dilakukan.

\section{DAFTAR PUSTAKA}

Abdau, P.D., Winarno, W.W., Henderi. 2018. Evaluasi Penerapan SIMRS Menggunakan Metode Hot-Fit Di RSUD Dr. Soedirman. Jurnal Penelitian dan Penerapan Teknologi Sistem Informasi. 2(1): 46-56.

Akhiroh, K. 2008. Persepsi Pengguna Terhadap Kualitas Layanan Di UPT Perpustakaan Instiper Yogyakarta. Yogyakarta: UIN Sunan Kalijaga.

Anand, T., Ingle, G. K., Kishore, J., Kumar, R. 2013. ABC-VED Analysis of a Drug Store in the Department of Community Medicine, Indian Journal of Pharmaceutical Sciences. 75(1): 113-117.

Bayu, A.S., Izzati, M. 2013. Evaluasi Faktor-Faktor Kesuksesan Implementasi Sistem Informasi manajemen Rumah Sakit di PKU Muhammadiyah Sruweng dengan Menggunakan Metode Hot-Fit. Seminar Nasional Informatika Medis (SNIMed) IV. 78-86. 
Betri, T.J. 2017. Perancangan Arsitektur Aplikasi Learning Management System Di Universitas Slamet Riyadi. Indonesian Journal of Applied Informatics. 2(1): 1-16.

Bodnar, G.H. 2003. Sistem Informasi Akuntansi. Jakarta: Gramedia.

Darwanis D., Mahyani, D. 2009. Pengaruh Kapasitas Sumber Daya Manusia, Pemanfaatan Teknologi Informasi dan Pengendalian Intern Akuntansi Terhadap Keterandalan Pelaporan Keuangan Pemerintah Daerah. Jurnal Telaah dan Riset Akuntansi. 2(2): 133-151.

DeLone, W. H., McLean E.R. 2003. The DeLone and McLean Model of Information Systems Success: A Ten Year Update. Journal of Management Information Systems. 19(4): 9 - 30.

Departemen Kesehatan Republik Indonesia. 2009. Sistem Kesehatan Nasional. Jakarta.

Departemen Kesehatan Republik Indonesia. 2010. Pedoman Pengelolaan Perbekalan Farmasi di Rumah Sakit. Direktorat Jenderal Pelayanan Kefarmasian dan Alat Kesehatan. Jakarta.

Diana, A., Setiawati, L. 2010. Sistem Informasi Akuntansi. Yogyakarta: Penerbit Andi.

Dwibarto, R. 2017. Evaluasi Penggunaan Sistem Informasi Manajemen Obat Pada Instalasi Farmasi Rumah Sakit Grhasia Yogyakarta. Seminar Nasional Teknologi Informasi Kesehatan (Snatik) 2017. 28-32.

Erimalata, S. 2016. Pendekatan Hot-Fit Framework dalam Generalized Structural Component Analysis pada Sistem Informasi Manajemen Barang Milik Daerah: Sebuah Pengujian Efek Resiprokal. Jurnal Akuntansi dan Investasi. 17(2): 141-157.

Erlirianto, L.M., Ali, A.H.N., Herdiyanti, A. 2015. The Implementation of the Human, Organization, and Technology-Fit (HOT-Fit) Framework to Evaluate the Electronic Medical Record (EMR) System in a Hospital. Procedia Computer Science. 72(1): 580-587.

Evania, N., Taufik, T., Hasan, M.A. 2016. Pengaruh Penggunaan Teknologi Informasi, Keahlian Pemakai, Dan Intensitas Pemakaian Terhadap Kualitas Informasi Akuntansi. Jurnal Ilmu Ekonomi. 3(1): 635-649.

Groho, T.C.M., Winarno, W.W., Permanasari, A.E. 2014. Evaluasi Kesuksesan Implementasi Aplikasi Pengelolaan Tugas Belajar Di BPK. Seminar Nasional Informatika 2014. 2(2): 11-17.

Guimaraes, T., Staples, D.S., Keen, J.D. 2003. Empirically Testing Some Main User Related Factor for Systems Development Quality. Quality Management Journal. 10(4), 39-54.

Gursel, G., Zayim, N., Gulkesen, K.H. 2014. A New Approach in the Evaluation of Hospital Information Systems. Turkish Journal of Electrical Engineering and Computer Sciences. 22(6): 214 - 222.

Hariningsih, E. 2014. Kajian Teori Model Penelitian Untuk Menilai Kesuksesan Dan Evaluasi Sistem Informasi Rumah Sakit. Jurnal Bisnis Manajemen dan Akuntansi. 2(1): 14-23.

Hendra, S., Sukardi, Syahrullah. 2015. Pengaruh Penggunaan E-Learning Klasiber terhadap Net Benefit. Yogyakarta: Seminar Nasional Aplikasi Teknologi Informasi.

Istianingsih, Wijanto, S. 2008. Pengaruh Kualitas Sistem Informasi, Perceived Usefulness, dan Kualitas Informasi Terhadap Kepuasan Pengguna Akhir. Pontianak: Simposium Nasional Akuntansi XI.

Kazemi, A., Rabiei, R., Hamid, M., Deimazar, G. 2016. Pharmacy Information Systems in Teaching Hospitals: A Multi-dimensional Evaluation Study, Healthcare Informatics Research. 22(3): 231-237.

Kodarisman, R., Nugroho, E. 2013. Evaluasi Penerapan Sistem Informasi Manajemen Kepegawaian (SIMPEG) di Pemerintah Kota Bogor. Jurnal Teknik Elektro dan Teknologi Informasi. 2(2): 24-32.

Krisbiantoro, D., Suyanto, M., Luthfi, E.T. 2015. Evaluasi Keberhasilan Implementasi Sistem Informasi Dengan Pendekatan Hot Fit Model. Konferensi Nasional Sistem \& Informatika 2015. 896-901.

Lestari, Marina, Kertahadi, Suyadi, M. 2013, Efektivitas Sistem Informasi Direktorat Jenderal Pajak (Studi Pada Kantor Pelayanan Pajak (KPP) Pratama Malang Utara). Jurnal Administrasi Bisnis. 6(2): 13-25.

McGill, T., Hobbs, V., Klobas J. 2013. Users Developed Application and Information System Success: A Test of Delone and McLean's Model. Information Resource Management Journal. 16 (1): 24-45.

Murnita, R., Sediyono, E., Purnami, C.T. 2016. Evaluasi Kinerja Sistem Informasi Manajemen Farmasi Di Rs Roemani Dengan Metode Hot Fit Model. Jurnal Manajemen Kesehatan Indonesia. 4(1): 11-19. 
Musrifah. 2017. Implementasi Teknologi Informasi Menggunakan Human Organization Technology (HOT) Fit Model Di Perpustakaan Perguruan Tinggi. Jurnal Ilmu Perpustakaan dan Informasi. 2(2): 222-242.

Nasir, J. A., Satoto, K. I., Kridalukmana, R. 2014. Sistem Informasi Pengelolaan Obat Di Instalasi Farmasi Dinas Kesehatan Kabupaten Pekalongan. Jurnal Teknologi dan Sistem Komputer. 2(1): 71-78.

Noerlina. 2009. Rancangan Sistem Informasi Rumah Sakit. Communication and Information Technology Journal. 3(1): 12-19.

Nurlani, L., Permana, B. 2017. Analisa Kesuksesan Sistem Informasi Akademik menggunakan Model Terintegrasi. Jurnal Teknologi Rekayasa. 2(2): 105-116.

Perwira, I.R. 2016. Kesesuaian Model HOT-FIT Dalam Sistem Informasi Elearning. Seminar Nasional Informatika (SEMNASIF). 1(2): 119-125.

Poluan, F., Arie, L., Alicia, S. 2014. Evaluasi Implementasi Sistem E-Learning Menggunakan Model Evaluasi HOT Fit. E-Journal Teknik Informatika. 4(2): 8-15.

Putra, W,M., Alfian, M. 2016. Pengujian Kesuksesan Implementasi Sistem Informasi Akuntansi Lembaga Keuangan Mikro: Modified Delone Mcleon Model. Jurnal Akuntansi dan Investasi. 17(1): 53-65.

Prasetyowati, A., Kushartanti, R. 2018. Pengaruh Faktor HOT (Human, Organisasi, Dan Teknologi) Terhadap Kepuasan Pengguna Sistem Informasi Primary Care Di Wilayah Kota Semarang. Jurnal Manajemen Informasi Kesehatan Indonesia. 6(1): 63-67.

Riauwi, H.M., Hasneli, N.Y., Lestari, W. 2014 Efektivitas Pendidikan Kesehatan Dengan Penerapan The Health Belief Model. Jurnal Online Mahasiswa Program Studi Ilmu Keperawatan. 1(2): 1-9.

Romney, B.M. 2003. Sistem Informasi Akuntansi. Jakarta: Gramedia.

Rozanda, N., Masriana, A. 2017. Perbandingan Metode Hot Fit dan Tam dalam Mengevaluasi Penerapan Sistem Informasi Manajemen Kepegawaian (SIMPEG). Seminar Nasional Teknologi Informasi. Komunikasi dan Industri. Fakultas Sains dan Teknologi. 327-336.

Santoso, H., 2012. Kajian Efektivitas Sistem Informasi Pangkalpinang Education Cyber City (PECC). Bangka Belitung: Dinas Pendidikan Kota Pangkal Pinang.

Sari, M.M., Sanjaya, G.Y., Meliala, A. 2016. Evaluasi Sistem Informasi Manajemen Rumah Sakit (Simrs) Dengan Kerangka Hot - Fit. Seminar Nasional Sistem Informasi Indonesia. 203-208.

Satibi, 2015. Manajemen Obat di Rumah Sakit. Yogyakarta: Gadjah Mada University Press.

Sheikhtaheri, A., Sadoughi, F., Ahmadi, M., Moghaddasi, M. 2013. A Framework of A Patient Safety Information System for Iranian Hospitals: Lessons Learned from Australia, England and the US. International Journal of Medical Informatics. 82(5): 335-344.

Westerling, M.A., Haikala V., Airaksinen M. 2011. The Role Of Information Technology In The Development of Community Pharmacy Services: Vision And Strategic Views Of International Experts, Helsinki Finland: Division Of Social Pharmacy Faculty Of Pharmacy University Of Helsinki.

Yessy, I.P., Hermanto, Handajani, L. 2016. Analisis Determinan Implementasi Sistem Akuntansi Instansi Berbasis Aktrual. Jurnal InFestasi. 12(2): 173-184.

Yusof, M.M., Kuljis, J., Papazafeiropoulou, A., Stergioulas, L.K. 2008. An Evaluation Framework For Health Information Systems: HOT-Fit. Int J Med Inform. 7(7): 386-398. 